\title{
Sağlık Hizmetleri Meslek Yüksekokulu Öğrencilerinin Demografik Özellikleri ile Gelecekteki Ekonomik Beklentileri Arasındaki İlişskinin İncelenmesi
}

\author{
İbrahim ÇİNAR
}

İzmir Kâtip Çelebi Üniversitesi Sağlık Hizmetleri Meslek Yüksekokulu, İzmir

\begin{tabular}{ccc}
\hline Geliş Tarihi & Kabul Tarihi & Yayın Tarihi \\
18.02 .2021 & 17.05 .2021 & 30.08 .2021 \\
\hline
\end{tabular}

Özet: Bu araștırma Sağlık Hizmetleri Meslek Yüksekokulu öğrencilerinin demografik verileri ile gelecekteki ekonomik beklentileri arasındaki ilişkiyi belirleyebilmek amacıyla yapılmıştır. Araştırma Sağlık Hizmetleri Meslek Yüksekokulu öğrencileri ile 2020-2021 eğitim-öğretim yılı güz döneminde anket yöntemiyle online olarak uygulanmıştır. Araştırmaya 376 öğrenci katılmıştır. Araştırma sonuçları ki-kare yöntemiyle SPSS 20 programı aracılığıyla analiz edilmiştir. Araştırma sonuçlarına göre öğrencilerin mezuniyet sonrası mesleki beklentileri, ekonomik koşul beklentileri, yurtiçi veya yurtdışında çalışma beklentileri, öğrencilerin eğitimleri esnasında öğrendiği becerilerin iş bulma konusunda diğerlerinden pozitif yönde ayıracağını düşünüyor musunuz sorusu, iş olanakları beklentileri ile öğrencilerin demografik verileri arasındaki bazı değişkenlerle ilişkili olduğu tespit edilmiştir. Araştırma sonuçları tablolar halinde gösterilmiştir. Araştırma sonuçlarına göre Sağlık Hizmetleri Meslek Yüksekokullarındaki öğrencilerin istihdamına katkı sağlayacak şekilde yeniden planlanması önerilmektedir.

Anahtar kelimeler: Beklenti, Ekonomi, Sağlık Hizmetleri MYO.

\section{Analysis Of The Relationship Between The Demographic Features Of Healthcare Vocational School Students And The Future Economic Expectations}

\begin{abstract}
This research was carried out to determine the relationship between the demographic data of Health Services Vocational School students and their future economic expectations. The research was conducted online with the students of vocational of health school in the fall semester of the 2020-2021 academic year using a survey method. 376 students participated in the study. The research results were analyzed with the chi-square method using the SPSS 20 program. According to the results of the research, it has been determined that there are some variables between the students 'professional expectations after graduation, economic conditions expectations, working at home or abroad, do you think that the skills learned during their education will distinguish them positively from others in finding a job, job opportunities expectations and students' demographic data. Research results are shown in tables. According to the results of the research, it is recommended that Health Services Vocational School's be re-planned in a way to contribute to the employment of students.
\end{abstract}

Keywords: Economics, Expectation, Health School of Vocational

\footnotetext{
* Sorumlu yazar

İbrahim ÇİNAR

ibrahimcinar1982iktisat@hotmail.com
}

Çinar İ 0000-0003-1122-3130 


\section{GíRiş}

Beklenti, henüz gerçekleşmemiş bir olay ile ilgili, geçmiş deneyimler ve güncel bilgiler doğrultusunda var olan verilere bakarak bir gerçekliğin nasıl oluşacağını tahmin etme sürecidir. Bir toplumda karar alıcların beklentileri ile gerçekleşen sonuçlar elde edilen bilgiler doğru ve tutarlı olduğunda, genelde aynı yönlü olarak ortaya çıkmaktadır (Eğilmez, 2020). Sağlık işgücünü oluşturan yetişmiş sağlık çalışanları da ellerinde var olan politikacıların ve Sağlık Bakanlığı'nın açıklamaları, atama sayıları, kendi alanlarındaki mezun sayıları, ülke ekonomisini algılayış şekilleri gibi çeşitli geçmiş ve güncel veriler aracilığıla gelecekleri hakkında ekonomik beklentiler içerisine girebilmektedirler (Öztürk, 2017).

Sağlık işgücü çeşitli okullar tarafından yetiştirilmektedir. Bunlardan bir tanesi de Sağlık Hizmetleri Meslek Yüksekokullarıdır (SHMYO). $\mathrm{Bu}$ okullar, üniversiteler bünyesinde sağlık teknikeri yetiştirmek amacıyla oluşturulmuş, tekniker unvanı veren kuruluşlardır (Yüksek Öğretim Kurumu Meslek Atlası, 2019). Tekniker unvanı, 3795 sayılı kanuna göre lise sonrasında 2 yıllık meslek yüksekokulu eğitimi alanlara verilmektedir. Sağlık teknikeri, Sağlık Bakanlığı veya özel sağlık kuruluşlarının çeşitli kademelerinde çalışan, temel düzeyde sağlık bilgi ve becerisini edinmiş, büro işleri ve tıbbi cihazların hazırlanması ve kullanılmasının yanı sıra hastaların ilk müdahalesi, tedavisi, rehabilitasyonu gibi çeşitli kademelerde yer alan 2 yllık meslek eğitimi almış, meslek yüksekokulu mezunu çalışanlardır. Türkiye'de mesleki eğitimi tercih edenlerin bazı özellikleri dikkat çekmektedir. Bu okullarda okuyanların genel özellikleri incelendiğinde, sosyo-ekonomik ve eğitim düzeyi düşük ailelerden geldikleri, bir an önce eğitim alıp iş bulmak isteyenlerden oluştukları görülür (Erdoğan ve Akın, 2016; Şen ve ark., 2016; Gümüş ve Şen, 2018; Kahya, 2020; Olğun ve Yıldırım, 2019; Taşkıran ve ark., 2020). İş beklentilerinin meslek eğitimi vermeyen okullara göre daha yüksek olduğu (Çiçek ve Ünlü, 2019), öğrencilerin iş bulma endişesini yoğun olarak yaşadıkları (Benli ve Acar, 2017; Küçük ve ark., 2019), bu nedenle daha çok iş güvencesi sunan kamuda çalışmak istedikleri (Bardakçı, 2019; Kaval ve Gökoğlan, 2020; Taşkıran ve ark., 2020), meslek eğitimi programlarını seçim nedenlerinin (Öztürk ve ark., 2016), mesleklerini yapma istekliliklerinin (Açıkgöz, 2019; Temel ve ark., 2020), eğitim aldıkları programın ve sosyodemografik özelliklerinin (Tuncer, 2011; Contuk ve Nas, 2019; Temel ve ark., 2020) iş bulma kaygısını etkilediği belirtilmektedir (Öztürk ve ark., 2016). Mezunlar işe girme sürecinde ve işten istedikleri geliri elde etme yönünde de sorunlar yaşadıklarını ifade etmişlerdir (Acar, 2020; Baltacı, 2020; Temel ve ark., 2020). Ayrıca meslek yüksekokulunda eğitim görenlerin ilk yıl ve son yll iş bulma beklentilerinin değiştiği gözlenmektedir (Contuk ve Nas, 2019). Günümüz meslek yüksekokulu eğitimi alanlar daha çok $\mathrm{Z}$ kuşağı diye tarif edilen toplum kesiminden oluşmaktadır. Bu kesimin iyi bir ücret, terfi olanakları ve iş güvencesi peşinde koştuğu bilinmektedir (Kızıldağ ve Cansever, 2019; Gölpek ve Yıldız, 2019; Turan ve Kayıkçı, 2019). Eğitim alan öğrenciler arasında bazı programlarda gelecek beklentileri olumlu yöndeyken (Ünlü ve ark., 2019), bazı programlarda mesleğini yapmayı düşünen öğrenci oranı ile yurt dışında çalışma istekliliğinin yüksek olduğu görülmektedir (Benli ve Acar, 2017). Türkiye İstatistik Kurumu (TÜİK) verilerine göre teknisyenler, teknikerler ve yardımcı profesyonel meslek mensuplarının Türkiye'de 2019 yılı yıllık gelirleri ortalamasının $37959 \mathrm{TL}$, aylık gelir ortalamasının $3163 \mathrm{TL}$ olduğu belirtilmektedir (TÜİK, 2021).

2019 yılı itibariyle Yüksek Öğretim Kurumu Meslek Atlası aracılığıyla elde edilen bilgilere göre araştırmada örneklem grubu olarak düşünülen Ağız ve Diş Sağlığı, Fizyoterapi, İlk ve Acil Yardım, Yaşlı Bakımı programlarına yerleşen öğrenci sayıları Tablo 1'de belirtilmiştir.

Tablo 1. Programlara Göre Yerleșen Öğrenci Sayıları (Yüksek Öğretim Kurumu Meslek Atlası, 2019).

\begin{tabular}{lcc}
\hline Program Adı & $\begin{array}{c}\text { Yerleşen } \\
\text { Öğrenci } \\
\text { Sayısı }\end{array}$ & $\begin{array}{c}\text { Doluluk } \\
\text { Oranı }\end{array}$ \\
\hline Ağız ve Diş Sağlığı & 4284 & $\% 94.7$ \\
Fizyoterapi & 6620 & $\% 95$ \\
İlk ve Acil Yardım & 12748 & $\% 98.8$ \\
Yaşlı Bakımı (Örgün) & 5450 & $\% 99$ \\
Yaşlı Bakımı (Açık) & 2395 & $\% 93.4$ \\
\hline
\end{tabular}


Tablo 1'deki programlara yerleşen öğrencilerin eğitim aldığ incelendiğinde, İlk ve Acil Yardım programında yaklaşık 50.000 mezunun atama beklediğ ortalama her yıl 1000-2000 arası atama yapıldığı (Kamubiz, 2020) belirtilmektedir. Yaşlı Bakımı programında yaklașık 35.000 mezun olduğu ve kamuda istihdamının yeterli olmadı $\breve{g}$ ifade edilmiş (Öztürk, 2019), fizyoterapistlik mesleği için 2018 yllında mezunların \%50'sinin işsiz olduğu ve işsizlik oranının artmaya devam edeceği (Algun ve Düger, 2019) öngörülmüştür. Ağız ve Diş Sağlığı programı diğer programlarda olduğu gibi mezun sayıları hızla artan ancak henüz istihdam sorunu görünmeyen programlardandır. Öğrencilerin bu programlara gelme beklentilerinin sıklıkla iş bulma yönünde olması dolayısıyla öğrencilerin gelecek ekonomik beklentilerinin bilinmesi oldukça önemlidir. $\mathrm{Bu}$ nedenle SHMYO öğrencilerinin demografik özellikleri ile ekonomik beklentileri arasındaki ilişkiyi belirleyebilmek amacıyla bu araştırma planlanmıştır.

\section{GEREÇ ve YÖNTEM}

Araştırma, alan yazın doğrultusundaki bilgilere dayanarak oluşturulmuş anket formu aracılığıyla uygulanmıştır. Anket formu 25 çoktan seçmeli sorudan oluşmaktadır. Sorulardan 19 tanesi öğrencilerin demografik özelliklerini belirlemeye yönelik, 6 tanesi gelecek ile ilgili beklentileri ölçmek içindir. Anket uygulanmadan önce İzmir Kâtip Çelebi Üniversitesi Sosyal Araştırmalar Etik Kurulundan etik onay alınmıştır (04.09.2020 tarihli 2020/09-12 sayılı karar). Anket Sağlık Hizmetleri Meslek Yüksekokulunda 1. Sinıf ve 2. Sinıf öğrencilerinin tümüne, öğrenciler ve öğretim elemanlarının haberleşmek için kullanmakta olduğu Whatsup öğrenci grupları aracılığıyla, gerekli etik bilgilendirme yapılarak 2020-2021 güz döneminde online olarak uygulanmıștır. Uygulama öncesinde anket sorularında herhangi bir sorun olup olmadığ $\breve{\text {, }}$ anlaşılma durumu, seçeneklerin uygunluğu, önyargıların varlığı, soruların yönlendirme yapıp yapmadığı, ölçülmek istenilenle sorunun aynı amaca mı yönelik olduğu gibi değerlendirmeleri yapabilmek için en az 20 öğrenci ile online ön test yapılmış, test sonucunda herhangi bir öneri gelmemiştir. Nihai düzen sonrasında anketler tüm okula uygulanmıştır. Online anket uygulaması esnasında öğrenciler formu yalnız bir kez doldurabilmişler, anketi gönderdikten sonra tekrar düzenleyememişlerdir. Anket sorularının tümü doldurulmadan form gönderimi sağlanamamıştır. Araştırmanın sonuçları SPSS 20 programı aracılığıyla sayı-yüzde ve ki-kare analizi yardımıyla çözümlenmiştir. Araştırmanın tek merkezli olarak yapılmış olması, bu merkezde 4 programın bulunması ve Covid-19 pandemi döneminde yapılması araştırmanın kısıtlılıklarını oluşturmaktadır.

\section{BULGULAR}

Araştırmanın bu kısmında araştırma sonucunda elde edilen bulgular tablolar halinde sunulmuştur. Tablolarda sunulan bulgular araştırmaya katılan öğrencilerin demografik özellikleri (Tablo 2) ile araştırmaya katılan öğrencilerin ekonomik beklentileri (Tablo 3) arasındaki ilişkide anlamlı bulunan sonuçlardan oluşmaktadır. Anlamsız ilişki bulunan sonuçlar tablolarda gösterilmemiştir. Demografik veriler içerisinde olup da tablolarda yer almayan değişkenlerle, ekonomik beklentiler arasında herhangi bir anlamlı ilişki olmadığı söylenebilir ( $p>0.05)$.

Tablo 2. Araştırmaya Katılan Öğrencilerin Demografik Özellikleri

\begin{tabular}{lcc}
\hline Program? & Sayı (n) & Yüzde (\%) \\
Ağız ve Diş Sağlı̆̆ı & 110 & 29.3 \\
Fizyoterapi & 80 & 21.3 \\
İlk ve Acil Yardım & 123 & 32.7 \\
Yaşlı Bakımı & 63 & 16.8 \\
\hline Sınıf? & & \\
1.sınıf & 206 & 54.8 \\
2.sınıf & 170 & 45.2 \\
\hline Cinsiyet? & & \\
\hline
\end{tabular}




\begin{tabular}{|c|c|c|}
\hline Kadın & 256 & 68.1 \\
\hline Erkek & 120 & 31.9 \\
\hline \multicolumn{3}{|l|}{ Yaş? } \\
\hline $17-21$ & 328 & 87.2 \\
\hline 22 ve üstü & 48 & 12.8 \\
\hline \multicolumn{3}{|l|}{ İkamet durumunuz? } \\
\hline Ailem eğitim aldığım şehirde yaşamıyor & 252 & 67.0 \\
\hline Ailemle birlikte eğitim aldığım șehirde yaşıyorum & 124 & 33.0 \\
\hline \multicolumn{3}{|l|}{ Anne eğitim düzeyi? } \\
\hline İlköğretim ve altı & 301 & 80.1 \\
\hline Lise & 58 & 15.4 \\
\hline Üniversite (Önlisans, Lisans, Yüksek Lisans) & 17 & 4.5 \\
\hline \multicolumn{3}{|l|}{ Baba eğitim düzeyi? } \\
\hline İlköğretim ve altı & 218 & 58 \\
\hline Lise & 103 & 27.4 \\
\hline Üniversite (Önlisans, Lisans, Yüksek Lisans) & 55 & 14.6 \\
\hline \multicolumn{3}{|l|}{ Anne-Babanızın evlilik durumu? } \\
\hline Evli & 347 & 92.3 \\
\hline Boșanmiș & 29 & 7.7 \\
\hline \multicolumn{3}{|l|}{ Anne-Babanın yaşama durumu? } \\
\hline Annem sağ babam vefat etti & 16 & 4.3 \\
\hline Annem vefat etti babam sağ & 2 & 0.5 \\
\hline İkisi de sağ & 357 & 94.9 \\
\hline İkisi de vefat etti & 1 & 0.3 \\
\hline \multicolumn{3}{|l|}{ En uzun yaşanılan yerleșim yeri? } \\
\hline Köy & 77 & 20.5 \\
\hline İlçe & 113 & 30.1 \\
\hline İl & 186 & 49.5 \\
\hline \multicolumn{3}{|l|}{ Kardeş sayınız? } \\
\hline $1-2$ & 200 & 53.2 \\
\hline $3-4$ & 102 & 27.1 \\
\hline 5 ve üzeri & 59 & 15.7 \\
\hline Yok & 15 & 4.0 \\
\hline \multicolumn{3}{|l|}{ Ailenizin gelir durumu? } \\
\hline Gelirimiz giderimizden az & 134 & 35.6 \\
\hline Gelirimiz giderimize denk & 214 & 56.9 \\
\hline Gelirimiz giderimizden fazla & 28 & 7.4 \\
\hline \multicolumn{3}{|l|}{ Ailenizde çalışan kişi sayısını belirtiniz? } \\
\hline 0 & 28 & 7.4 \\
\hline 1 & 219 & 58.2 \\
\hline 2 & 102 & 27.1 \\
\hline 3 & 21 & 5.6 \\
\hline 4 ve üstü & 6 & 1.6 \\
\hline \multicolumn{3}{|c|}{ Üniversite eğitiminiz esnasında eğitim masraflarınızı nasıl karşılıyorsunuz? } \\
\hline Ailem + Burs/Kredi & 57 & 15.2 \\
\hline Ailem & 187 & 49.7 \\
\hline Burs/Kredi & 42 & 11.2 \\
\hline Kendim + Burs/Kredi & 15 & 4.0 \\
\hline Kendim & 43 & 11.4 \\
\hline Diğer & 13 & 3.5 \\
\hline \multicolumn{3}{|c|}{ Üniversite eğitiminiz esnasında gelir getirici bir işte çalışıyor musunuz? } \\
\hline Kamu çalışanıyım & 10 & 2.7 \\
\hline Kendime ait işyerim var & 6 & 1.6 \\
\hline Özel sektörde tam zamanlı çalışıyorum & 7 & 1.9 \\
\hline Özel sektörde yarı zamanlı çalıșıyorum & 38 & 10.1 \\
\hline Çalışmiyorum & 315 & 83.8 \\
\hline \multicolumn{3}{|c|}{ Üniversite yașamınızda yaklașık olarak aylık harcamanız ne kadardır? } \\
\hline $0-500 \mathrm{TL}$ & 111 & 29.5 \\
\hline $501-1000 \mathrm{TL}$ & 159 & 42.3 \\
\hline $1001-1500 \mathrm{TL}$ & 61 & 16,2 \\
\hline $1501-2000 \mathrm{TL}$ & 29 & 7,7 \\
\hline $2001-2500 \mathrm{TL}$ & 10 & 2.7 \\
\hline 2501 TL ve üzeri & 6 & 1.6 \\
\hline \multicolumn{3}{|l|}{ Üniversite tercih sebebinizi belirtiniz? } \\
\hline Ailemin isteği doğrultusunda & 17 & 4.5 \\
\hline Eğitim almak istediğim bölüm olduğu için & 226 & 60.1 \\
\hline
\end{tabular}




\begin{tabular}{lcc}
\hline Hatalı tercih yaptım & 11 & 2.9 \\
İş garantisi olduğu için & 48 & 12.8 \\
Sınav puanım bu bölüme yettiği için & 64 & 17.0 \\
Üniversite mezunu olmak istediğim için & 10 & 2.7 \\
\hline Yeniden üniversite tercih hakkınız olsaydı eğitim aldığınız programı & & \\
yeniden tercih eder miydiniz? & 193 & 51.3 \\
Evet & 75 & 19.9 \\
Hayır & 108 & 28.7 \\
Kararsızım & & \\
\hline Ailenizde sağlık çalışanı var mıdır? & 57 & 15.2 \\
Evet & 319 & 84.8 \\
Hayır & 376 & 100 \\
Toplam & \multicolumn{2}{c}{} \\
\hline
\end{tabular}

Tablo 3. Araștırmaya Katılan Öğrencilerin Ekonomik Beklentileri

\begin{tabular}{|c|c|c|}
\hline Mezun olduktan sonra çalıșma şeklinizin nasıl olmasını bekliyorsunuz? & $\underline{\text { Sayı (n) }}$ & Yüzde (\%) \\
\hline Kamu çalıșanı olacağım & 246 & 65.4 \\
\hline Kendi işimin sahibi olacağım & 30 & 8.0 \\
\hline Özel sektörde çalıșacağım & 57 & 15.2 \\
\hline İșsiz kalacağım & 43 & 11.4 \\
\hline \multicolumn{3}{|l|}{ Mezuniyet sonrası mesleki beklentiniz nedir? } \\
\hline Eğitimimi arttırıp mesleğimle ilgili kariyer yapmak istiyorum & 163 & 43.4 \\
\hline Mezun olduğum program dışında bir iş yapmak istiyorum & 35 & 9.3 \\
\hline Mezun olduğum programla ilgili bir iş yapmak istiyorum & 178 & 47.3 \\
\hline \multicolumn{3}{|l|}{$\begin{array}{l}\text { Eğitim aldığınız programla ilgili mezuniyet sonrasında iş olanaklarına ilişkin } \\
\text { düşünceniz nedir? }\end{array}$} \\
\hline İş olanakları artacak & 155 & 41.2 \\
\hline İş olanakları azalacak & 86 & 22.9 \\
\hline İș olanakları değişmeyecek & 135 & 35.9 \\
\hline \multicolumn{3}{|l|}{$\begin{array}{l}\text { Size mezuniyet sonrası yurtiçi veya yurtdışı çalışma şansı verilseydi } \\
\text { tercihiniz ne olurdu? }\end{array}$} \\
\hline Yurtiçinde çalışırdım & 120 & 31.9 \\
\hline Yurtdıșında çalıșırdım & 212 & 56.4 \\
\hline Kararsızım & 44 & 11.7 \\
\hline \multicolumn{3}{|l|}{$\begin{array}{l}\text { Eğitiminiz esnasında öğrendiğiniz becerilerin sizi iş bulma konusunda } \\
\text { diğerlerinde pozitif yönde ayrıştıracağını düşünüyor musunuz? }\end{array}$} \\
\hline Evet & 285 & 75.8 \\
\hline Hayır & 36 & 9.6 \\
\hline Kararsızım & 55 & 14.6 \\
\hline \multicolumn{3}{|l|}{$\begin{array}{l}\text { Mezuniyet sonrasında eğitim aldığınız mesleği yaptığınızda ekonomik } \\
\text { koșullarınızın nasıl olacağını beklemektesiniz? }\end{array}$} \\
\hline İyi & 77 & 20.5 \\
\hline Orta & 268 & 71.3 \\
\hline Kötü & 31 & 8.2 \\
\hline Toplam & 376 & 100 \\
\hline
\end{tabular}

Araştırmaya katılan öğrencilerin tanımlayıcı özellikleri Tablo 2 aracıllğıyla gösterilmektedir. Tablo 2'ye göre, araştırmaya [ $\mathrm{n}=123$ (\%32.7)] öğrenci ile en çok İlk ve Acil Yardım Programı öğrencilerinin katılım gösterdiği görülürken, 1. sinıfların [n=206 (\%54.8)], 2. sinıflara göre, kadınların [ $\mathrm{n}=256$ (\%68.1)], erkeklere göre daha fazla katılım gösterdiği görülmektedir. 17-21 yaş grubunun [n=328 (\%87.2)], 22 ve üstü yaş grubuna göre araştırmada daha fazla yer aldığı ortaya çlkarken, bu yaş grubunun fazla olmasının meslek yüksekokulunda eğitim gören öğrenci yaş aralığıyla uyumlu olduğu düșünülmektedir. Araștırmaya katılan öğrencilerin çoğunluğunun [n=252 (\%67)] şehir dışında eğitim almak için İzmir'e geldiği sonucuna varılmıştır. Öğrencilerin annelerin eğitim düzeyinin büyük oranda ilköğretim ve altı seviyede olduğu [n=301 (\%80.1)], görülürken, babalarının eğitim düzeyinin annelerinden biraz daha yüksek olduğu ancak yine de $[n=218$ (\%58.0)] büyük oranda ilköğretim ve altı düzeyde eğitim seviyesine sahip oldukları ortaya çıkmıştır. $\mathrm{Bu}$ durumun Türkiye'de kız çocuklarının eğitimine erkek çocuklar kadar önem verilmemesi sonucunu doğuran 
geleneksel yaklaşımlarla uyumlu olduğu görülmektedir. Ayrıca meslek yüksekokuluna gelen öğrencilerin, fakültelere giden öğrencilere göre daha düşük puan aldıkları düşünüldüğünde, anne ve baba eğitim düzeyinin düşüklüğü ile sınavlardan alınan puanların ilişkili olabileceği düşünülmektedir. Öğrencilerin anne-babalarının büyük oranda evli oldukları [n=347 (\%92.3)] görülürken, yine büyük oranda anne ve babanın her ikisinin de sağ olduğu [n=357 (\%94.9)] sonucuna varılmıştır. Öğrencilerin en uzun yaşadıkları yerleşim yerinin il olduğu [n=186 (\%49.5)], 1-2 kardeşi olduğu belirtenlerin [ $\mathrm{n}=200$ (\%53.2)] sayısının diğerlerinden fazla olduğu görülmektedir. Öğrencilerin gelirlerine ilișkin sorulan sorulara verilen yanitlar incelendiğinde, [ $n=214$ (\%56.9)] öğrenci gelirleri ve giderlerinin denk olduğunu, çoğunlukla ailede çalışan sayısının 1 kişi olduğu [ $n=219$ (\%58.2)], eğitim masraflarının öğrencilerin yaklaşık yarısının sadece aileleri tarafından karşılandığg [n=187 (\%49.7)], öğrencilerin büyük çoğunluğunun eğitimleri esnasında gelir getirici bir işte çalışmadıkları [n=315 (\%83.8)], aylık harcamalarının sıklıkla 501-1000 TL arasında olduğu [n=159 (\%42.3)] sonucuna varılmıştır. Öğrencilerin üniversite tercihlerini çoğunlukla kendi istedikleri bölüme yaptıkları [ $\mathrm{n}=226$ (\% 60.1)], öğrencilerin yaklaşık yarısının tekrar üniversite tercih şansı olsaydı aynı programı tercih etmek istediği [n=193 (\%51.3)], ailesinde sağlık çalışanı olmayanların [ $\mathrm{n}=319$ (\% 84.8)] sayısının oldukça yüksek olduğu görülmüştür.

Araştırmaya katılan öğrencilerin ekonomik beklentilerine ilişkin sorulan sorular ve yanıtları Tablo 3'de görülmektedir. Öğrenciler mezun olduktan sonra büyük oranda kamu çalışanı olmak istediklerini $\quad[n=246 \quad(\% 65.4)]$ belirtmişlerdir. Mezuniyet sonrasında mezun oldukları programla ilgili bir iş yapmak istediğini söyleyenler [ $\mathrm{n}=178$ (\%47.3)], az da olsa mezun olduktan sonra mesleğiyle ilgili kariyer yapmak isteyen öğrencilerden [ $\mathrm{n}=163 \quad(\% 43.4)]$ fazla sayıdadır. Her iki yanıtın uyumlu olması öğrencilerin hem mesleklerini yapmak istedikleri hem de çalışırken mesleklerinin kariyer imkânlarını değerlendirme yönünde eğilimleri olduğunu düşündürmektedir. Öğrenciler mezuniyet sonrasında kendi alanlarıyla ilgili iş olanaklarının artacağını [n=155 (\%41.2)] düşünmektedirler. Bununla birlikte mezun olduktan sonra yurtdışında çalışma imkanı olsa bunu tercih edeceklerin sayısının yüksek olduğu [n=212 (\%56.4)] görülmektedir. Öğrencilerin büyük çoğunluğu aldıkları eğitimin iş bulma konusunda kendilerini diğerlerinden olumlu yönde ayıracağını [n=285 (\%75.8)] ifade etmişlerdir. Mezuniyet sonrasında ekonomik durumlarının büyük oranda orta düzeyde oluşacağ $[n=268$ (\%71.3)] beklentisi içerisindedirler. Bu sonucun ara eleman yetiştiren meslek yüksekokulu öğrencileri için beklenen bir gelişme olduğu söylenebilir.

Araştırmaya katılan öğrencilerin demografik özellikleri ile mezuniyet sonrasında mesleki beklentileri arasındaki ilişki Tablo 4 yardımıyla gösterilmiştir. Tablo 4'de öğrencilerin eğitim gördükleri programlar, cinsiyetleri, ikamet durumları, eğitimleri esnasında masraflarını karşılama şekilleri, üniversite tercih sebepleri ve yeniden üniversite tercih hakları olsaydı eğitim aldıkları programları tekrar seçme durumları, arasında anlamlı bir ilişki tespit edilmiştir $(\mathrm{p}<0,05)$.

Araştırmaya katılan öğrencilerin demografik özellikleri ile mezuniyet sonrasında yurtiçinde veya yurtdışında çalışma beklentisi arasındaki ilişki Tablo 6 yardımıyla gösterilmiștir. Tablo 6'ya göre öğrencilerin üniversite tercih sebebi ve yeniden üniversite tercih hakları olsaydı eğitim aldığı programı tekrar tercih eder miydi yanıtları ile yurtiçi ve yurt dışında çalışma beklentisi arasında anlamlı bir ilişki tespit edilmiştir $(\mathrm{p}<0,05)$.

Araştırmaya katılan öğrencilerin demografik özellikleriyle öğrencilerin eğitimleri esnasında öğrendiği becerilerin iş bulma konusunda diğerlerinden pozitif yönde ayıracağını düşünüyor musunuz sorusu arasındaki ilişki Tablo 7 yardımıyla gösterilmiştir. Tablo 7'ye göre göre öğrencilerin programları, sınıfları, üniversite tercih sebebi ve yeniden üniversite tercih hakları olsaydı eğitim aldığı programı tekrar tercih eder miydi yanıtları ile eğitimleri 
esnasında öğrendiği becerilerin iş bulma konusunda diğerlerinden pozitif yönde ayıracağını düşünüyor musunuz sorusu arasında anlamlı bir ilişki tespit edilmiştir $(\mathrm{p}<0,05)$.

Tablo 8 araştırmaya katılan öğrencilerin demografik özellikleri ile eğitim aldıkları alanda iş olanakları beklentileri arasındaki ilişski gösterilmiştir. Tablo 8'e göre öğrencilerin programları, sınıfları, kardeş sayıları, üniversite tercih sebebi ve yeniden üniversite tercih hakları olsaydı eğitim aldığı programı tekrar tercih eder miydi yanıtları ile mezuniyet sonrası iş beklentileri arasında anlamlı bir ilişki tespit edilmiștir $(\mathrm{p}<0,05)$.

Tablo 4. Demografik Değişsenlerle Öğrencilerin Mezuniyet Sonrası Mesleki Beklentileri Arasındaki İlișki

\begin{tabular}{|c|c|c|c|c|}
\hline \multirow[t]{3}{*}{ Demografik Değişkenler } & \multicolumn{4}{|c|}{ Mezuniyet sonrası mesleki beklenti } \\
\hline & $\begin{array}{c}\text { Eğitimimi } \\
\text { arttırıp } \\
\text { mesleğimle ilgili } \\
\text { kariyer yapmak } \\
\text { istiyorum. }\end{array}$ & $\begin{array}{l}\text { Mezun olduğum } \\
\text { program dişında } \\
\text { bir iș yapmak } \\
\text { istiyorum }\end{array}$ & $\begin{array}{l}\text { Mezun olduğum } \\
\text { programla ilgili } \\
\text { bir iș yapmak } \\
\text { istiyorum }\end{array}$ & İstatistik \\
\hline & Sayı/Yüzde & Sayı/Yüzde & Sayı/Yüzde & $\mathrm{X}^{2} /$ Fisher's Exact \\
\hline \multicolumn{5}{|l|}{ Program? } \\
\hline Ağız ve Diş Sağlığı & 25 (22.7) & 8 (22.9) & $77(43.3)$ & $X^{2}=83.930$ \\
\hline Fizyoterapi & $53(66.2)$ & $4(11.4)$ & $23(12.9)$ & $\mathrm{p}=0.000$ \\
\hline İlk ve Acil Yardım & $46(37.4)$ & $7(20.0)$ & $70(39.3)$ & \\
\hline Yaşlı Bakımı & $39(61.9)$ & $16(45.7)$ & $8(4.5)$ & \\
\hline \multicolumn{5}{|l|}{ Cinsiyet? } \\
\hline Kadın & $119(73)$ & $17(48.6)$ & $120(67.4)$ & $\mathrm{p}=0.021$ \\
\hline Erkek & $44(27)$ & $18(51.4)$ & $58(32.6)$ & \\
\hline \multicolumn{5}{|l|}{ İkamet durumunuz? } \\
\hline $\begin{array}{l}\text { Ailem eğitim aldığım şehirde } \\
\text { yașamıyor }\end{array}$ & $97(59.5)$ & $29(82.9)$ & $126(70.8)$ & $\mathrm{p}=0.010$ \\
\hline $\begin{array}{l}\text { Ailemle birlikte eğitim aldığım } \\
\text { șehirde yașıyorum }\end{array}$ & $66(40.5)$ & $6(17.1)$ & $52(29.2)$ & \\
\hline \multicolumn{5}{|l|}{$\begin{array}{l}\text { Üniversite eğitiminiz esnasında } \\
\text { eğitim masraflarınızı nasıl } \\
\text { karsılıyorsunuz? }\end{array}$} \\
\hline Ailem + Burs/Kredi & $20(12.3)$ & 8 (22.9) & $29(16.3)$ & \\
\hline Ailem & $89(54.6)$ & $11(31.4)$ & $87(48.9)$ & $X^{2}=83.930$ \\
\hline Burs/Kredi & $18(11.0)$ & $3(8.6)$ & $21(11.8)$ & $\mathrm{p}=0.001$ \\
\hline Kendim +Ailem + Burs/Kredi & $4(2.5)$ & $7(20)$ & $8(4.5)$ & \\
\hline Kendim + Burs/Kredi & $8(4.9)$ & $3(8.6)$ & $4(2.2)$ & \\
\hline Kendim & $20(12.3)$ & - & $23(12.9)$ & \\
\hline Diğer & $4(2.5)$ & $3(8.6)$ & $6(3.4)$ & \\
\hline \multicolumn{5}{|l|}{$\begin{array}{l}\text { Üniversite tercih sebebinizi } \\
\text { belirtiniz? }\end{array}$} \\
\hline Eğitim almak istediğim bölüm olduğu & & & & $\mathrm{p}=0.000$ \\
\hline için & $100(61.3)$ & $5(14.3)$ & $121(68.0)$ & \\
\hline İș garantisi olduğu için & $19(11.7$ & $7(20.0$ & $22(12.4$ & \\
\hline Sınav puanım bu bölüme yettiği için & $35(21.5)$ & $12(34.3)$ & $17(9.6)$ & \\
\hline Diğer* & $9(5.5)$ & $11(31.4)$ & $38(10.1)$ & \\
\hline \multicolumn{5}{|l|}{$\begin{array}{l}\text { Yeniden üniversite tercih hakkınız } \\
\text { olsaydı eğitim aldığınız programı } \\
\text { yeniden tercih eder miydiniz? }\end{array}$} \\
\hline Evet & $78(40.4)$ & $2(1.0)$ & $113(58.5)$ & \\
\hline Hayır & $30(40.0)$ & $23(30.7)$ & $22(29.3)$ & $\mathrm{p}=0.000$ \\
\hline Kararsızım & $55(50.9)$ & $10(9.3)$ & $43(39.8)$ & \\
\hline
\end{tabular}

$\mathrm{X}^{2}=$ Ki-Kare. FE:Fisher Exact Test (Bower, 2003). *Diğer: Hatalı tercih yaptım, ailemin isteği doğrultusunda tercih yaptım, üniversite mezunu olmak istediğim için tercih yaptım. 
Tablo 5. Demografik Değişkenlerle Mezuniyet Sonrasında Ekonomik Koşul Beklentisi Arasındaki İlişki

\begin{tabular}{|c|c|c|c|c|}
\hline \multirow[t]{3}{*}{ Demografik Değişkenler } & \multicolumn{3}{|c|}{ Mezuniyet sonrası ekonomik koşul beklentisi } & \multirow{3}{*}{$\begin{array}{c}\text { İstatistik } \\
\text { Fisher's Exact }\end{array}$} \\
\hline & İyi & Orta & Kötü & \\
\hline & Sayı/Yüzde & Sayı/Yüzde & Sayı/Yüzde & \\
\hline \multicolumn{5}{|l|}{ Program? } \\
\hline Ağız ve Diș Sağlığı & $22(28.6)$ & $75(28.0)$ & $13(41.9)$ & $\mathrm{p}=0.013$ \\
\hline Fizyoterapi & $15(19.5)$ & $61(22.8)$ & $4(12.9)$ & \\
\hline İlk ve Acil Yardım & $29(37.7)$ & $91(34.0)$ & $3(9.7)$ & \\
\hline Yaşlı Bakımı & $11(14.3)$ & $41(15.3)$ & $11(35.5)$ & \\
\hline \multicolumn{5}{|l|}{ Anne eğitim düzeyi? } \\
\hline İlköğretim ve altı & $59(76.6)$ & $217(81.0)$ & $25(80.6)$ & $\mathrm{p}=0.008$ \\
\hline Lise & $18(23.4)$ & $38(14.2)$ & $2(6.5)$ & \\
\hline Üniversite (Önlisans, Lisans, Yüksek Lisans) & - & $13(4.9)$ & $4(12.9)$ & \\
\hline \multicolumn{5}{|l|}{$\begin{array}{l}\text { Üniversite yaşamınızda yaklaşık olarak } \\
\text { aylık harcamanız ne kadardır? }\end{array}$} \\
\hline $0-500 \mathrm{TL}$ & $33(42.9)$ & $75(28.0)$ & $3(9.7)$ & \\
\hline $501-1000 \mathrm{TL}$ & $34(44.2)$ & $113(42.2)$ & $12(38.7)$ & $\mathrm{p}=0.001$ \\
\hline $1001-1500 \mathrm{TL}$ & $6(7.8)$ & $46(17.2)$ & $9(29.0)$ & \\
\hline 1501 ve üzeri & $4(5.2)$ & $34(12.7)$ & $7(22.6)$ & \\
\hline \multicolumn{5}{|l|}{ Üniversite tercih sebebinizi belirtiniz? } \\
\hline Eğitim almak istediğim bölüm olduğu için & $54(70.1)$ & $163(60.8)$ & $9(29.0)$ & \\
\hline İş garantisi olduğu için & $8(10.4)$ & $35(13.1)$ & $5(16.1)$ & $\mathrm{p}=0.002$ \\
\hline Sınav puanım bu bölüme yettiği için & $12(15.6)$ & $44(16.4)$ & $8(25.8)$ & \\
\hline Diğer* & $3(3.9)$ & $26(9.7)$ & $9(29.0)$ & \\
\hline \multicolumn{5}{|l|}{$\begin{array}{l}\text { Yeniden üniversite tercih hakkınız } \\
\text { olsaydı eğitim aldığınız programı yeniden } \\
\text { tercih eder miydiniz? }\end{array}$} \\
\hline Evet & $55(71.4)$ & $129(48.1)$ & $9(29.0)$ & \\
\hline Hayır & $7(9.1)$ & $56(20.9)$ & $12(38.7)$ & $\mathrm{p}=0.000$ \\
\hline Kararsızım & $15(19.5)$ & $83(31.0)$ & $10(32.3)$ & \\
\hline
\end{tabular}

FE:Fisher Exact Test (Bower, 2003). *Diğer:Hatalı tercih yaptım, ailemin isteği doğrultusunda tercih yaptım, üniversite mezunu olmak istediğim için tercih yaptım.

Tablo 6. Demografik Değişkenlerle Mezuniyet Sonrası Yurtiçi veya Yurtdışında Çalışma Beklentisi Arasındaki İlișki

\begin{tabular}{|c|c|c|c|c|}
\hline \multirow[t]{3}{*}{ Demografik Değişkenler } & \multicolumn{4}{|c|}{ Mezuniyet sonrası yurtiçi veya yurtdışında çalışma beklentisi } \\
\hline & $\begin{array}{l}\text { Yurtiçinde } \\
\text { çalıșırdım }\end{array}$ & $\begin{array}{l}\text { Yurtdışında } \\
\text { çalışırdım }\end{array}$ & Kararsızım & İstatistik \\
\hline & Sayı/Yüzde & Sayı/Yüzde & Sayı/Yüzde & $\begin{array}{c}\text { Fisher's } \\
\text { Exact }\end{array}$ \\
\hline \multicolumn{5}{|l|}{ Üniversite tercih sebebinizi belirtiniz? } \\
\hline Eğitim almak istediğim bölüm olduğu için & $79(65.8)$ & $110(51.9)$ & $37(84.1)$ & \\
\hline İș garantisi olduğu için & $12(10.0)$ & $31(14.6)$ & $5(11.4)$ & $\mathrm{p}=0.001$ \\
\hline Sınav puanım bu bölüme yettiği için & $21(17.5)$ & $42(19.8)$ & $1(2.3)$ & \\
\hline Diğer* & $8(6.7)$ & $29(13.7)$ & $1(2.3)$ & \\
\hline \multicolumn{5}{|l|}{$\begin{array}{l}\text { Yeniden üniversite tercih hakkınız olsaydı } \\
\text { eğitim aldığınız programı yeniden tercih } \\
\text { eder miydiniz? }\end{array}$} \\
\hline Evet & 74 (61.7) & 93 (43.9) & $26(59.1)$ & \\
\hline Hayır & $19(15.8)$ & $53(25.0)$ & $3(6.8)$ & $\mathrm{p}=0.003$ \\
\hline Kararsızım & $27(22.5)$ & $66(31.1)$ & $15(34.1)$ & \\
\hline
\end{tabular}

FE: Fisher Exact Test (Bower, 2003). *Diğer: Hatalı tercih yaptım, ailemin isteği doğrultusunda tercih yaptım, üniversite mezunu olmak istediğim için tercih yaptım. 
Tablo 7. Demografik Değişkenlerle Öğrencilerin Eğitimleri Esnasında Öğrendiği Becerilerin İş Bulma Konusunda Diğerlerinden Pozitif Yönde Ayıracağını Düşünüyor Musunuz Sorusu Arasındaki İlișki

\begin{tabular}{|c|c|c|c|c|}
\hline \multirow[t]{3}{*}{ Demografik Değişkenler } & \multicolumn{4}{|c|}{$\begin{array}{l}\text { Öğrencilerin eğitimleri esnasında öğrendiği becerilerin iş bulma } \\
\text { konusunda diğerlerinden pozitif yönde ayıracağını düşünüyor } \\
\text { musunuz? }\end{array}$} \\
\hline & Evet & Hayır & Kararsızım & İstatistik \\
\hline & Sayı/Yüzde & Sayı/Yüzde & Sayı/Yüzde & Fisher's Exact \\
\hline \multicolumn{5}{|l|}{ Program? } \\
\hline Ağız ve Diș Sağlığı & $85(29.8)$ & $12(33.3)$ & $13(23.6)$ & $\mathrm{p}=0.015$ \\
\hline Fizyoterapi & $50(17.5)$ & $9(25.0)$ & $21(38.2)$ & \\
\hline İlk ve Acil Yardım & $104(36.5)$ & $7(19.4)$ & 12 (21.8) & \\
\hline Yaşlı Bakımı & $46(16.1)$ & $8(22.2)$ & $9(16.4)$ & \\
\hline \multicolumn{5}{|l|}{ Sinıf? } \\
\hline 1.sinif & $171(60.0)$ & $9(25)$ & $26(47.3)$ & $\mathrm{p}=0.000$ \\
\hline 2.sinif & $114(40.0)$ & $27(75)$ & $29(52.7)$ & \\
\hline \multicolumn{5}{|l|}{$\begin{array}{l}\text { Üniversite tercih sebebinizi } \\
\text { belirtiniz? }\end{array}$} \\
\hline $\begin{array}{l}\text { Eğitim almak istediğim bölüm olduğu } \\
\text { için }\end{array}$ & $183(64.2)$ & $15(41.7)$ & $28(50.9)$ & $\mathrm{p}=0.006$ \\
\hline İş garantisi olduğu için & $37(13.0)$ & 5 (13.9) & $6(10.9)$ & \\
\hline Sınav puanım bu bölüme yettiği için & $46(16.1)$ & $8(22.2)$ & $10(18.2)$ & \\
\hline Diğer* & $19(6.7)$ & $8(22.2)$ & $11(20)$ & \\
\hline \multicolumn{5}{|l|}{$\begin{array}{l}\text { Yeniden üniversite tercih hakkınız } \\
\text { olsaydı eğitim aldığınız programı } \\
\text { yeniden tercih eder miydiniz? }\end{array}$} \\
\hline Evet & 166 (58.2) & $9(25.0)$ & 18 (32.7) & \\
\hline Hayır & $42(14.7)$ & $17(47.2)$ & $16(29.1)$ & $\mathrm{p}=0.000$ \\
\hline Kararsızım & $77(27.0)$ & $10(27.8)$ & $21(38.2)$ & \\
\hline
\end{tabular}

FE: Fisher Exact Test (Bower, 2003). *Diğer: Hatalı tercih yaptım, ailemin isteği doğrultusunda tercih yaptım, üniversite mezunu olmak istediğim için tercih yaptım

Tablo 8. Demografik Değişkenlerle Mezuniyet Sonrasında Öğrencilerin Eğitim Aldıkları Alanda İş Olanakları Beklentileri Arasındaki İlişki

\begin{tabular}{|c|c|c|c|c|}
\hline \multirow[t]{3}{*}{ Demografik Değişkenler } & \multicolumn{4}{|c|}{ Mezuniyet sonrası iș olanakları beklentisi } \\
\hline & Artacak & Azalacak & Değișmeyecek & İstatistik \\
\hline & Sayı/Yüzde & Sayı/Yüzde & Sayı/Yüzde & Fisher's Exact \\
\hline \multicolumn{5}{|l|}{ Program? } \\
\hline Ağı ve Diș Sağlı̆̆ & $52(33.5)$ & $24(27.9)$ & $34(25.2)$ & $\mathrm{p}=0.026$ \\
\hline Fizyoterapi & $31(20.0)$ & $12(14.0)$ & $37(27.4)$ & \\
\hline İlk ve Acil Yardım & $43(27.7)$ & $40(46.5)$ & $40(29.6)$ & \\
\hline Yaşlı Bakımı & $29(18.7)$ & $10(11.6)$ & $24(17.8)$ & \\
\hline \multicolumn{5}{|l|}{ Sinif? } \\
\hline 1.sinif & $97(62.6)$ & $39(45.3)$ & $70(51.9)$ & $\mathrm{p}=0.026$ \\
\hline 2.sinif & $58(37.4)$ & $47(54.7)$ & $65(48.1)$ & \\
\hline \multicolumn{5}{|l|}{ Kardeş sayınız? } \\
\hline $1-2$ & $90(58.1)$ & $45(52.3)$ & $65(48.1)$ & $\mathrm{p}=0.033$ \\
\hline $3-4$ & 32 (20.6) & $22(25.6)$ & 48 (35.6) & \\
\hline 5 ve üzeri & $23(14.8)$ & $18(20.9)$ & $18(13.3)$ & \\
\hline Yok & $10(6.5)$ & $1(1.2)$ & $4(3.0)$ & \\
\hline \multicolumn{5}{|c|}{$\begin{array}{l}\text { Üniversite yaşamınızda yaklaşık } \\
\text { olarak aylık harcamanız ne } \\
\text { kadardır? }\end{array}$} \\
\hline $0-500 \mathrm{TL}$ & $53(34.2)$ & $18(20.9)$ & $40(29.6)$ & $\mathrm{p}=0.033$ \\
\hline $501-1000 \mathrm{TL}$ & $70(45.2)$ & $34(39.5)$ & $55(40.7)$ & \\
\hline $1001-1500 \mathrm{TL}$ & 20 (12.9) & $22(25.6)$ & 19 (14.1) & \\
\hline 1501 ve üzeri & $12(7.7)$ & $12(14.0)$ & $21(15.6)$ & \\
\hline \multicolumn{5}{|c|}{$\begin{array}{l}\text { Yeniden üniversite tercih hakkınız } \\
\text { olsaydı eğitim aldığınız programı } \\
\text { yeniden tercih eder miydiniz? }\end{array}$} \\
\hline Evet & $103(66.5)$ & 30 (34.9) & $60(44.4)$ & \\
\hline Hayır & $13(8.4)$ & 30 (34.9) & $32(23.7)$ & $\mathrm{p}=0.001$ \\
\hline Kararsızım & $39(25.2)$ & $26(30.2)$ & $43(31.9)$ & \\
\hline
\end{tabular}




\section{TARTIŞMA ve SONUÇ}

$\mathrm{Bu}$ araștırma Sağlık Hizmetleri Meslek Yüksekokulu öğrencilerin demografik özellikleri ile ekonomik beklentileri arasındaki ilişkiyi belirleyebilmek amacıyla yapılmıştır. Bu amaçla alan yazın doğrultusunda anket soruları oluşturulmuștur. Anketlerin uygunluğu ön test aracılığıyla değerlendirilmiştir. Daha sonra herhangi bir sorun olmadığı görülerek öğrencilere uygulanmıştır. Anketler online olarak toplanmıştır ve SPSS 20 programı aracılığıyla analiz edilmiştir. Anket sonuçları sayı yüzde ve ki-kare analizleri yardımıyla değerlendirilmiştir. Değerlendirme sonuçları tablolar halinde gösterilmiştir.

Araştırma sonuçlarına göre öğrencilerin eğitim aldıkları programları ile mezuniyet sonrası mesleki beklentileri, mezuniyet sonrası ekonomik koşul beklentileri, eğitimleri esnasında öğrendiği becerilerin iş bulma konusunda diğerlerinden pozitif yönde ayıracağına yönelik beklentileri ve mezuniyet sonrası iş olanakları beklentileri arasında anlamlı bir ilişski tespit edilmiştir $(p<0,05)$. Yaşlı Bakımı programı öğrencilerinin mesleki beklentileri (Tablo 4) ve ekonomik koşul beklentisi (Tablo 5) diğer programlardan ayrışmaktadır. İlk ve Acil Yardım programı öğrencileri eğitimlerinin iş bulma konusunda pozitif ayrıştıracağını daha yüksek oranda benimserlerken (Tablo 7), iş olanakları konusunda ki düşünceleri (Tablo 8) diğer programlara göre farklılaşmaktadır. Bu sonuçlar mesleklere ilişkin iş beklentilerine yönelik ifadeleri destekleyici yöndedir (Algun ve Düger, 2019; Öztürk, 2019). Tüm bu sonuçlar, bazı programlar arasında gelecek beklentilerinin farklılaştığını ifade eden (Ünlü ve ark., 2019), araştırma sonucuyla benzerlik göstermektedir.

Araştırma sonuçlarına göre öğrencilerin demografik özellikleri incelendiğinde araştırmaya katılan öğrencilerin anne veya babalarının eğitim düzeylerinin ilköğretim ve altı düzeyde olduğu görülmektedir (Tablo 2). Bu sonucun yapılan başka araştırmalarla (Erdoğan ve Akın, 2016; Şen ve ark., 2016; Gümüș ve Şen, 2018; Kahya, 2020; Olğun ve Yıldırım, 2019; Taşkıran ve ark., 2020) uyumlu olduğu görülmektedir. Ebeveynlerin eğitim düzeyinin düşüklügü ile üniversitelerdeki en alt eğitim düzeyi olan meslek yüksekokulunda eğitim görmenin ilişkili olduğu görülmektedir. Konuyla ilgili diğer okullarda eğitim gören öğrencilerin de demografik verilerinin karşılaştırılması ve anne baba eğitim düzeyiyle üniversitede okunan bölümün ilişkisinin incelenmesi önerilebilir.

Öğrencilerin ekonomik beklentileri incelendiğinde (Tablo 3), yurt dişında çalışma istekliliklerinin oldukça yüksek olduğu görülmektedir (\%56.4). Bu sonuç yapılan başka bir araştırmayla (Benli ve Acar, 2017) benzerlik göstermektedir. SHMYO gibi iş imkânlarının yüksek olduğu düşünülen bir okulun öğrencilerinin büyük oranda yurt dışında çalışma isteği içerisinde olmaları dikkate değer ve farklı araştırmalarla açıklanması gereken bir konudur.

Günümüz meslek yüksekokulu eğitimi alanlar daha çok Z kuşağı diye tarif edilen toplum kesiminden oluşmaktadır. Bu kesimin iyi bir ücret, terfi olanakları ve iş güvencesi peşinde koștuğu bilinmektedir (Kızıldağ ve Cansever, 2019; Gölpek ve Yıldız, 2019; Turan ve Kayıkçı, 2019). Araştırma sonuçlarına göre öğrencilerin \%43.4'ü kendi mesleklerinde kariyer yapmak isterken, \%47.3'ünün eğitim gördükleri programda çalışmak istedikleri görülmüştür (Tablo 3). Bu sonuçla öğrencilerin kendi mesleklerinde çalışırken kariyer olanaklarını da kullanmak istedikleri şeklinde yorumlanabilir. Z kuşağı içerisinde yer alan SHMYO öğrencilerinin de bu kuşağın özelliğini taşıdığı söylenebilir. Öğrencilerin eğitim gördükleri alandan mezuniyetleri sonrasında ücret beklentileri incelendiğinde (Tablo 3), 2324 TL ile 5000 TL arasında oluştuğu gözlemlenmiştir. Bu rakam TÜİK tarafından belirtilen Tekniker, Teknisyen ve Yardımcı Profesyonel meslek mensuplarının maaşlarının ortalamasındadır (Yıllık Ortalama: 37959, Aylık Ortalama: 3163). Öğrencilerin mezuniyet sonrası ekonomik koşulunu \%71.3 oranında orta olarak beklediği (Tablo 3) görülmektedir. $\mathrm{Bu}$ sonuç öğrencilerin iyi bir ücret beklentisinin, belirtilen $\mathrm{Z}$ kuşağ özelliklerine uygun olmadığını ya da iyi bir ücret tanımının kişiden kişiye değişebileceğini 
göstermektedir. Öğrencilerin iş beklentisi incelendiğinde, daha çok kamuda çalışmak istedikleri belirlenmiştir. Bu sonuç daha önce yapılan araştırmalarla (Bardakçı, 2019; Kaval ve Gökoğlan, 2020; Taşkıran ve ark., 2020) benzerlik göstermektedir. Ayrıca $\mathrm{Z}$ kuşağ özelliklerinde belirtilmiş olan iş güvencesi beklentisine ilişkin sonuçları teyit etmektedir.

Öğrencilerin kardeş sayıları ile ekonomik beklentileri arasında anlamlı bir ilişki tespit edilmiştir. $\mathrm{Bu}$ farklılı̆̆ın kardeş sayısı 1-2 olanlardan kaynaklandığı görülmüştür (Tablo 8). $\mathrm{Bu}$ öğrencilerin diğer öğrencilere göre iş olanakları beklentisinin artacağına yönelik düşüncelerinin daha yoğun olduğu görülmüştür. Bu sonuç kardeş sayılarının gelecek beklentisini etkilediğini gösteren sonuçlarla (Tuncer, 2011) benzerlik göstermektedir.

Öğrencilere sorulan, üniversite için yeniden tercih hakkınız olsaydı eğitim aldığınız programı yeniden tercih eder miydiniz sorusu ile mezuniyet sonrasındaki mesleki beklentilerinin (Tablo 4), mezuniyet sonrası ekonomik koşul beklentilerinin (Tablo 5), mezuniyet sonrası yurtiçinde veya yurt dişında çalışma beklentilerinin (Tablo 6), eğitimleri esnasında öğrendiği becerilerin iş bulma konusunda diğerlerinden pozitif yönde ayıracağını düşünüyor musunuz sorularının (Tablo 7) ve mezuniyet sonrasında iş olanakları beklentisinin (Tablo 8) anlamlı bir ilişki içinde olduğu görülmüştür. $\mathrm{Bu}$ durumun Tablo 1'de gösterildiği üzere iş beklentilerinin azalması nedeniyle olduğu düşünülmektedir. Konuyla ilgili yapılan başka araştırmalarda öğrencilerin SHMYO tercihi yaparken iş beklentilerinin ve iş bulma endişelerinin yüksek olduğu belirtilmiştir (Benli ve Acar, 2017; Çiçek ve Ünlü, 2019; Küçük ve ark., 2019). Araştırma sonuçlarının bu araştırmaları destekleyici yönde olduğu görülmektedir. Ayrıca öğrencilerin iş beklentilerinin ve iş bulma endişelerinin yüksek olmasının sosyo-ekonomik düzeyi düşük ailelerden gelmeleri ile de ilgili olduğu (Erdoğan ve Akın, 2016; Șen ve ark., 2016; Gümüş ve Şen, 2018; Kahya, 2020; Olğun ve Yıldırım, 2019; Taşkıran ve ark., 2020), böyle ailelerden gelen gençlerin aile ekonomisine bir an önce katkı verme çabası içerisine girdiği düşünülebilir. Bununla birlikte öğrencilerin iş olanakları konusundaki düşünceleri önemlidir. Öğrenciler sıklıkla (\%43.4) iş olanaklarının artacağı beklentisi içerisindedirler. Ancak yadsınamayacak bir öğrenci grubu (\%35.9) iş olanaklarının azalacağını düşünmektedir. Ayrıca öğrencilerin aylık harcamaları ile mezuniyet sonrası ekonomik koşul beklentisi (Tablo 5) ve iş olanakları beklentilerinin (Tablo 8) anlamlı bir ilişki içerisinde bulunduğu sonucuna varılmıștır. Aylık harcamaları 0-500 TL olarak belirten öğrencilerin diğer öğrenci gruplarına göre daha fazla iş beklentisi içerisinde oldukları (Tablo 5) ve iş olanaklarının azalacağına yönelik beklentilerinin düşük olduğu (Tablo 8) görülmektedir. Bu sonuç öğrencilerin bir an önce iş bulma beklentisi içerisinde olduğunu, sosyoekonomik düzeyi düşük ailelerden gelmeleri nedeniyle eğitim sonrasında hızla belirli bir gelir elde etmeyi hedeflediklerini (Erdoğan ve Akın, 2016; Şen ve ark., 2016; Gümüş ve Şen, 2018; Kahya, 2020; Olğun ve Yıldırım, 2019; Taşkıran ve ark., 2020), gösteren sonuçlarla doğru orantılıdır. Özellikle ekonomik durumu kötü olan öğrencilerin, eğitimleri sonunda gelir elde etme konusunda daha olumlu düşündükleri söylenebilir.

Öğrencilerin eğitimlerinin kendilerini iş bulma konusunda pozitif ayrıştıracağı düşüncesi ile öğrencilerin sınıfları arasında anlamlı bir ilişki tespit edilmiştir. Bu ilişki incelendiğinde 1. Sinıf öğrencilerinin 2. Sınıf öğrencilerine göre iş bulma konusunda daha olumlu düşündükleri görülmektedir (Tablo 7). Bu sonuç daha önce yapılan araştırmalarla (Contuk ve Nas, 2019) aynı yönde sonuç verdiği gibi konuyla ilgili yapılan anlamlı olmayan sonuçlar da (Tuncer, 2011) bulunmaktadır. Öğrencilerin iş bulma konusunda 2. Sinıfa geldiklerinde olumsuz düşüncelerinin oluşmasının nedeni olarak daha önce meslekleriyle ilgili yetersiz bilgilere sahip olabilecekleri, eğitimleri esnasında meslekleri ve mesleklerinin istihdam durumları ile ilgili daha doğru bilgi edinmiş olmaları gösterilebilir.

Araştırma sonuçları incelendiğinde SHMYO öğrencilerinin sosyo-ekonomik düzeyi düşük ailelerinin çocuklarının yoğun olarak eğitim 
aldığı bir okul olduğu görülmektedir. Öğrencilerin anne ve babalarının eğitim düzeylerinin düşük olması dikkate değer bir sonuçtur. Eğitim düzeyi düşük ebeveynlerin çocuklarının üniversitede en alt düzey eğitim sunan meslek yüksekokulunu tercih etmeleri ya da tercih etmek zorunda oldukları düşünülmektedir. $\mathrm{Bu}$ okullara gelen öğrenci grubunun aylık harcamalarının da mezun olduktan sonra gelir beklentilerinin de orta düzeyde olduğu görülmektedir. Ancak öğrencilerin kariyer yapma isteği içerisinde olmaları dikkat çeken bir sonuçtur. Öğrencilerin iş bulma endişelerinin oldukça yüksek olmasinın, bu okullardan mezun olan öğrencilere iş imkânı sağlanabilmesinin oldukça önemli olduğunu göstermektedir. Ancak günümüzde en çok iş imkânı sağladı̆̆g düşünülen okullardan olan SHMYO'ların daha önceki yıllarda olduğu gibi iş imkânı sağlayamadığı, okuldan mezun olanların işsizlik sorunuyla karşılaşabildiği ve yığılmalar olduğu görülmektedir. Bu yığılmaların umutları bir an önce iş bulmak olan gençlerin umutsuzluğa sürüklenmesine ve toplumsal bazı sorunlara yol açabileceği düşünülmektedir. Çok zor şartlarda okuyan veya okumaya çalışan öğrencilerin mezun olduktan sonra iş bulabilmelerinin oldukça önemli olduğu düşünülmekte, meslek yüksekokulu planlamalarının ve öğrenci kontenjanlarının, mezuniyet sonrasında iş bulunabilecek şekilde yeniden düzenlenmesi önerilmektedir. $\mathrm{Bu}$ şekilde planlamanın yapılmaması durumunda öğrencilerde ve ailelerinde nesiller boyunca kalıcı olacak yoksulluğun oluşabileceği öngörülmektedir. Öğrencilerin, özellikle SHMYO okuyanların yarıdan fazlasının yurt dışına gitmek istemeleri de bu bağlamda incelenmelidir. SHMYO öğrencilerinin durumundan, diğer okul ve fakültelerinin durumunun daha olumsuz olabileceği de tahmin edilmektedir. Bu nedenle meslek yüksekokulları yeniden planlanmalı, iş bulma güvencesi sağlayan programların açılmasına, iş sağlama güvencesini kaybeden programların dönüştürülmesine öncelik verilmelidir.

\section{Çıkar Çatışması}

$\mathrm{Bu}$ araștırmada herhangi bir kişi ya da kurumla ilgili çıkar çatışması bulunmamaktadır.

\section{KAYNAKLAR}

Acar S (2020) Kamu sağlık sektöründe beyaz yakalı tașeron çalışanlar: Fırat Üniversitesi Hastanesi Örneği. JECS 61 (1), 1-22.

Açıkgöz A (2019) Sağlık hizmetleri meslek yüksekokulu son sınıf öğrencilerinde umutsuzluk düzeyi ve ilișkili etmenler. SDUSBED 10 (1), 5-12.

\begin{abstract}
Algun ZC, Düger T (2019) Türkiye'de fizyoterapistlik mesleği. http://www.sdplatform.com/Dergi/1162/Turkiyed e-fizyoterapistlik-meslegi.aspx.. Erişim 12 Ekim 2020.
\end{abstract}

Baltacı IK (2020) Genç işsizliği ve geleceğe uzanan zorlu işgücü piyasası koşulları: Diyarbakır, Suriçi Bölgesi Örneği. AìD 53 (1), 119-152.

Bardakçı S (2019) Öğrencilerin üniversite ve bölüm tercihlerini etkileyen faktörlerin incelenmesi: Sivas Cumhuriyet Üniversitesi Sağllk Hizmetleri MYO örneği. CUMUiïBF 20 (2), 356-373.

Benli AR, Acar E (2017) Yaşlı Bakım Teknikerliği Bölümü son sınıf öğrencilerinin mesleklerine yönelik kaygı düzeyleri ve etkileyen faktörler. İTOBİAD 6 (5), 2512-2521.

Bower KM (2003) When to use Fisher's exact test. In American Society for Quality, Six Sigma. Forum Magazine 2 (4), 35-37.

Contuk Y, Nas Y (2019) Y kuşağının istihdam beklentileri üzerine bir inceleme: Fethiye Ali Sitkı Mefharet Koçman Meslek Yüksekokulu örneği. İJMEB 15 (2), 484-502.

Çiçek H, Ünlü G (2019) Z kuşağının kariyer beklentileri: Lise öğrencileri üzerinde bir uygulama. SELCUKSBMYD 22 (2), 447-458.

Eğilmez M (2020) Ekonomi Sözlüğü. http://www.mahfiegilmez.com/p/ekonomisozlugu.html. Erişim 21 Kasım 2020.

Erdoğan EG, Akın B (2016) Hemşirelik son sınıf öğrencilerinin iş bulma endişeleri ve umutsuzluk düzeyleri. EÜHFD 32 (1), 72-89.

Gölpek F, Yıldız K (2019) Kamu üniversitelerinde kayıtlı öğrencilerin sosyo-ekonomik statüsü üzerine bir araștırma: Şırnak Üniversitesi örneği. HİGHEREDU-SCI 9 (3), 460-473. 
Gümüş R, Şen MA (2018) Sağlık hizmetleri meslek yüksekokulu öğrencilerinin alan tercihlerinin ve mesleğe bakıș açılarının değerlendirilmesi. DUZGEF 33, 91-102.

Kahya Y (2020) Gençlerin yaşam kalitesi ve gelecek beklentileri. BMİj 8 (1), 950-968.

Kamubiz (2020) 50 bin paramedik atama bekliyor. http://www.kamubiz.com/saglik/50-binparamedik-atama-bekliyor-h4313.html. Erișim 5 Aralık 2020.

Kaval U, Gökoğlan K (2020) Üniversite öğrencilerinin kariyer eğilimleri: Dicle Üniversitesi örneği. DİİBFD 10 (19), 248-260.

Kızıldağ D, Cansever D (2019) Z kuşağı ne ister? İşveren markası perspektifinden üniversite öğrencilerine yönelik bir araştırma. SOBİAD Ekonomi \& Siyaset Özel Sayısı, 303-324.

Küçük U, Usta G, Torpuş K (2019) Sağlık hizmetleri meslek yüksekokulu son sınıf öğrencilerinin iş bulma endișeleri ve umutsuzluk düzeyleri. ACU Sağlık Bil Derg 10 (3), 367-372.

Olğun S, Yıldırım B (2019) Yaşlı bakımı ve evde hasta bakımı programı öğrencilerinin öğrenim gördükleri programa ilişkin görüş ve beklentileri. Hem Bil Derg 2 (2), 9-13.

Öztürk A (2019) Bölüm var atama yok!!!. https://www.istiklal.com.tr/kose-yazisi/bolum-varatama-yok/425649. Erişim 24 Ekim 2020.

Öztürk F (2017) Sağlıkçılar uyarıyor: 470 bin diplomalı sağlıkçı atanmayı bekliyor. BBC. https://www.bbc.com/turkce/haberler-dunya42416586. Erişim 11 Ekim 2020.

Öztürk M, Yurdagül G, Tatlıbadem B (2016) Yaşlı bakım teknikeri öğrencilerinin bölüme yönelik düşüncelerinin umutsuzluk düzeylerine etkisi. Güm Üni Sağlık Bil Derg 5 (2), 1-9.

Şen A, Erdivanlı B, Hüseyinoğlu Ü, Köksal E, Çeğin MB, Silay E, Tomak Y (2016) Anestezi teknikerlerinin shmyo eğitimiyle ilgili görüşleri ve mesleki beklentileri: Anket çalışması. Kafkas J Med Sci 6 (2), 110-114.

Taşkıran N, Kalı N, Kıvrak EN, Türkseven N, Yıldırım GÖ (2020) Son sınıf hemşirelik öğrencilerinin hemşirelik mesleğine, rollerine ve mesleğin geleceğine ilişkin görüşleri. Hast Önc Derg 5 (1), 43-56.

Temel M, Çelikkalp Ü, Bilgiç Ş, Saraçoğlu GV (2020) Hemşirelik öğrencilerinin mezuniyet sonrasına yönelik mesleki kaygıları ve etkileyen faktörler. ATAUNIHEM 23 (1), 23-34.
Tuncer M (2011) Yükseköğretim gençliğinin gelecek beklentileri üzerine bir araştırma. Elect Turkish Stud 6 (2), 935-948.

Turan Ü, Kayıkçı K (2019) Lise son sınıf öğrencilerin meslek seçiminde ailenin rolü. Elect Turkish Stud 14 (4), 2797-2816.

Türkiye İstatistik Kurumu (TÜİK) (2021) Gelir dağılımı ve yaşam koşulları istatistikleri. http://tuik.gov.tr/PreTablo.do?alt id=1011 . Erişim 15 Şubat 2021.

Ünlü TN, Bakkal E, Gökbudak A (2019) Tıbbi sekreterlerin mesleklerini algılama biçimleri ve gelecekten beklentileri. Biruni Üni. Sağlık ve Eğitim Bil Derg 3 (Bahar), 1-10.

Yüksek Öğretim Kurumu Meslek Atlası (2019) https://yokatlas.yok.gov.tr/meslekonlisans.php?b=19548. Erișim 27 Ekim 2020.

Zencir G (2016) Hemşirelik öğrencilerinin hemşirelik mesleğine yönelik tutumları ile hemşirelik tercihi arasındaki ilişki: Türkiye Örneği. DEUHYOD 9 (2), 30-37. 